\title{
Isolation and Preliminary Identification of Resistant (Salophilic) Microorganisms in Daqing
}

Dexi Shi, Wenbo Cao, Yan Hong, Jiao Zhong, Shuang Zhan, Zhen Jiang, Ming Gao, Guihua Wang, Yanhong Wang*

College of Life Science and Technology, HeiLongJiang BaYi Agricultural University, Daqing 163319, China

DOI: $10.36347 /$ sjet.2020.v08i01.003

| Received: 08.01.2020 | Accepted: 15.01.2020 | Published: 18.01.2020

*Corresponding author: Yanhong Wang

Abstract

Original Research Article

Halophilic bacteria have special metabolic mechanism and physiological structure, which can change soil properties to achieve economic benefits, and have great research value and development potential. The development of new salttolerant strains can tap the strain potential and contribute genotypes of new strains to the database. The ultimate goal is to improve the crop yield, enrich the variety of planted crops and increase the utilization rate of saline-alkali land. So as to improve the soil conditions to increase food production, protect the environment and green saline land and other goals. Targeted enrichment method and liquid dilution coated plate method were used to isolate and screen bacteria with high salt tolerance, and then phylogenetic analysis method based on 16S rDNA gene sequence was used to establish the bacterial gene tree.

Keywords: Separation, Appraisal, Salinity tolerance, Phylogenetic analysis, PCR.

Copyright @ 2020: This is an open-access article distributed under the terms of the Creative Commons Attribution license which permits unrestricted use, distribution, and reproduction in any medium for non-commercial use (NonCommercial, or CC-BY-NC) provided the original author and source are credited.

\section{INTRODUCTION}

Now the land salinization is serious, in order to improve the soil environment, we need to use chemical, physical, biological and other ways to carry out experiments. Biology as the common method to improving soil salinization is the joint action of plants and salt-tolerant microorganisms. Nowadays, due to the pursuit of efficiency, people generally only choose efficient chemical reagents, which leads to the aggravation of land consolidation and is one of the causes of land salinization. Studies have shown that nitrogen-fixing bacteria, rhizobia and other microbial fertilizers have stronger affinity to soil and almost no negative effect on soil. Therefore, if a new salt-tolerant microorganism is found, it can effectively provide value for improving land salinization. At the same time, it can also provide new gene fragments for transgenic plants, which provides a reference for constructing efficient transgenic saline-tolerant plants. As a new microbial resource with great development value, saltenvironment microorganisms have their unique biological groups, special physiological structure, metabolic mechanism and genetic genes. Because there are excellent characters, so the development potential is great, suitable for development and utilization.

\section{MATERIALS AND METHODS \\ Bacterial Culture Medium}

Salinity of the $\mathrm{S}-\mathrm{G}$ medium: ryptone, $10 \mathrm{~g} / \mathrm{L}$, yeast extract, $5 \mathrm{~g} / \mathrm{L}$, casein, $5 \mathrm{~g} / \mathrm{L}, \mathrm{KCl}, 2 \mathrm{~g} / \mathrm{L}$, sodium citrate, $3 \mathrm{~g} / \mathrm{L}, \mathrm{MgSO}_{4} \cdot 7 \mathrm{H}_{2} \mathrm{O}, 20 \mathrm{~g} / \mathrm{L}$, distilled water, 1000 $\mathrm{mL}, 15 \mathrm{~g} / \mathrm{L}$ agar was added to prepare solid screening medium. For the enrichment, isolation and screening of salt-tolerant bacteria [1], $\mathrm{NaCl}$ was selected in accordance with the required concentration requirements. When the solid medium is configured, $\mathrm{KOH}$ is used to regulate the medium, because its positive ions are $\mathrm{K}^{+}$and will not affect the concentration of $\mathrm{Na}^{+}$.

\section{Classification of salt-tolerant and salt-loving microorganisms}

There are five types of microbial tolerance to salt [2], the optimum growth salinity $(\mathrm{NaCl}$ concentration) of non-halophilic bacteria was less than $2 \%$. The optimum growth salinity was $2 \% \sim 5 \%$. Moderate halophilic bacteria, the optimum growth salinity is $5 \% \sim 20 \%$. Extremely halophilic bacteria, optimum growth salinity $15 \% \sim 30 \%$. Salt-tolerant bacteria, the optimal growth salinity is more than $25 \%$, among which some extreme halophilic bacteria are halophilic archaea [3]. In recent years, through $16 \mathrm{~S}$ rRNA gene research and analysis [4], many scholars 
have found a large number of salt-tolerant and saltloving fungi groups growing in the ocean, salt lake, salt field and saline-alkali land. Such as Hanaerobiales mesh (Firmicutes door) and Halomonadaceae family (Gammaproteo bacteria classes) are all halophilic [5].

\section{Enrichment and Isolation of Halophilic Bacteria}

Using the liquid medium directional enrichment method. The samples were placed in a sterilized $250 \mathrm{~mL}$ conical flask containing $5 \%$ (w/v) $\mathrm{NaCl}, 160 \mathrm{r} / \mathrm{min}$, and shock cultured at $28^{\circ} \mathrm{C}$. The bacterial enrichment process was ended when the bacterial solution became turbidized and the bacterial concentration reached the point where it could be screened. By using liquid dilution coated tablet, will complete the bacteria suspension of enrichment in $0.9 \%$ $(\mathrm{w} / \mathrm{v})$ sterile saline classification dilution. Then $0.1 \mathrm{~mL}$ of bacterial suspensions of various concentrations were absorbed and coated on the modified S-G medium containing 5\%,10\%, $15 \%$ and $20 \%$ (w/v) $\mathrm{NaCl}$ series of plates $[6,7]$, and the single colony removed was transferred to a clean liquid medium and cultured to a suitable concentration.

\section{Extraction of Genomic DNA from Bacteria}

A bacterial genome kit was used to extract the bacterial genome of the target species. By centrifugation cracking bacterial genes, through splitphase, filter, combination and elution steps, will do well the genome of the gel electrophoresis, gel, spot, run 10 min, observations. PCR products with suitable amplified fragment length, no obvious heterozygosity and high purity were selected and sent to bgi for product sequencing. Seqman was used to splix the upper and lower fragments of sequencing results, and the primer fragments were manually deleted. The wrong bases were modified with stable bases of wave peaks through find conflict. The splaining sequence was saved in seq format, opened in test format, and the sequence was modified in fasta format, and the sequence name was named.

\section{Based on 16S rDNA gene sequence established bacteria phylogenetic tree \\ DNAMAN 6.0 software was used to compare} the $16 \mathrm{~S}$ rDNA gene sequence returned to us. Bacteria whose sequence similarity was $\geq 99.9 \%$ were discarded as the same strain temporarily. If the similarity is less than $99 \%$, it is temporarily regarded as a new strain, and a sequence with less homology is selected as the representative sequence. Submit the representative sequence to GenBank database, analyze and find the serial number. Using blast search online analysis, the genomes with high similarity and homology of representative sequences were searched in NCBI database. With MEGA 5 application CLUSTAL W for sequence alignment, the Neighbor - Joining method, using the bootstrap is found that the proposed new bacteria genetic tree is established. Genetic tree analysis, preliminary determine the strains of bacteria.
Halophilic bacteria - determination of resistance to alkalinity

Mainly based on the determination of alkali resistance under different concentration, the growth of bacteria, according to the results of the determination of salt resistance, the ratio of salt concentration and had the same growth conditions, $\mathrm{pH}$ value was adjusted to $6.0,7.0,8.0,9.0,10.0,11.0,12.0$, the salinity of the $\mathrm{S}$ $\mathrm{G}$ medium plate, will select representative bacteria inoculation on the tablet, $28{ }^{\circ} \mathrm{C}$ inversion training after 3 $\mathrm{d}$ to observe the growth of bacteria.

\section{RESULTS AND ANALYSIS}

After the enrichment and preliminary screening of the bacterial liquid, it could be seen that the bacterial liquid in the conical flask became cloudy and had a relatively atmospheric taste after the first colony enrichment, which basically indicated that there were bacteria in it for large-scale reproduction. After 7 days of culture, the color of the bacterial liquid was yellow with obvious turbidity (Figure-1).

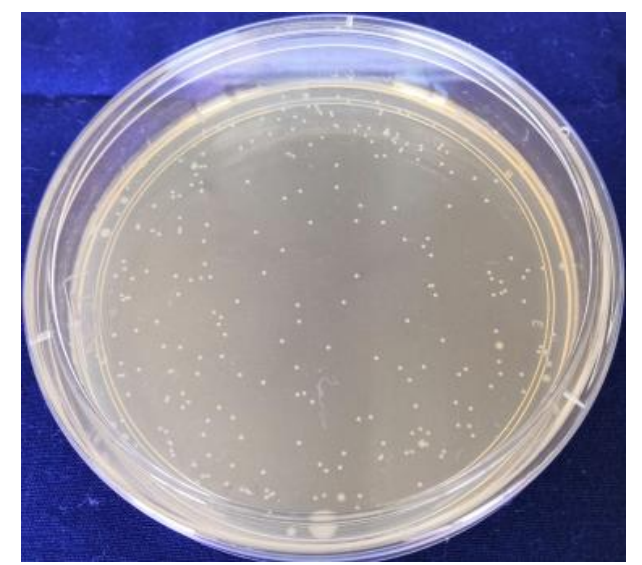

Fig-1: Bacteria growing at salt concentration of $1 \mathrm{~mol} / \mathrm{L}$

The bacteria were initially screened with medium with different salinity concentrations, and were coated with solid medium with salt concentrations of $5 \%, 10 \%, 15 \%$ and $20 \%$, respectively, and cultured at $28^{\circ} \mathrm{C}$ to observe the colony growth. The suitable individual colonies of high-salinity tolerant bacteria were selected and transferred to the liquid medium for reproduction. After dilution to the appropriate concentration, the molar concentration was selected for plate screening to determine the range of salt tolerance. Strains were selected and labeled for liquid culture, and tubes with good growth conditions were selected for bacterial genome extraction, and then PCR was used to obtain the amplified DNA fragments for examination (Figure-2). 


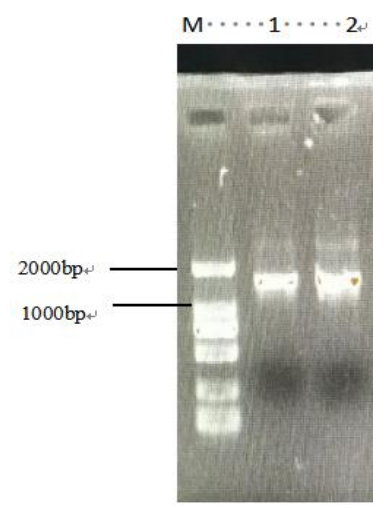

Fig-2: Agarose gel electrophoresis of 16SrDNA
In salt under the same conditions of use for the cultivation of the $\mathrm{pH}$, observe its growth conditions. The alkali resistance was determined to be between 7 and 10, and the growth was not good beyond this range, so the alkali resistance was determined and sequenced, the bacteria with low similarity were selected as the representative bacteria. The sequence of the detected strain was compared in GenBank database of NCBI to construct the bacterial gene tree and understand its biological morphology and traits. It was found that CGM20190520 belongs to the genus bacillus, and its gene sequence is the gene tree as shown in the Figure-3.

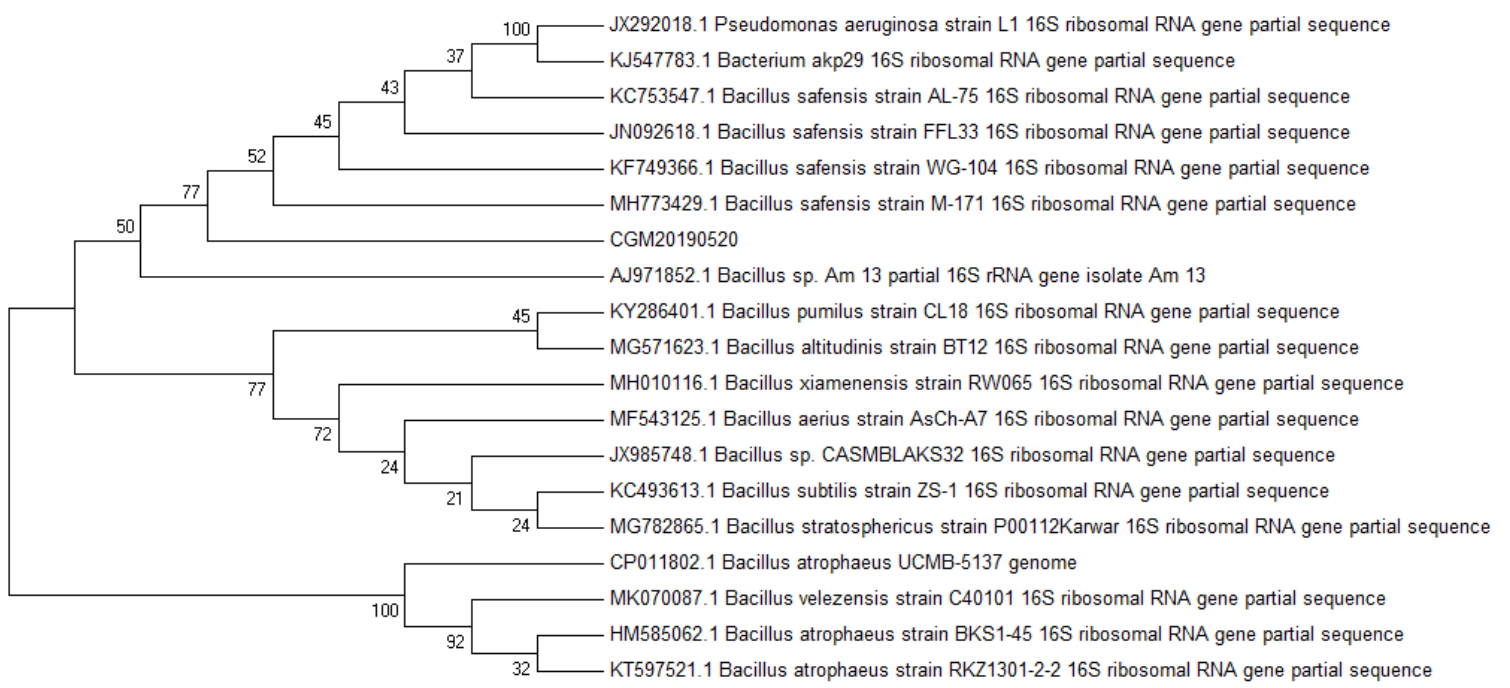

Fig-3: Establishment of bacterial genome tree based on 16S rDNA gene sequence (CGM20190520 is the proposed discovery of new bacteria)

According to the test results, among the 10 strains tested, 5 strains had the tolerance of $5 \%(\mathrm{w} / \mathrm{v})$ $\mathrm{NaCl}, 4$ strains had the tolerance of $10 \%(\mathrm{w} / \mathrm{v}) \mathrm{NaCl}, 2$ strains had the tolerance of $15 \%(\mathrm{w} / \mathrm{v}) \mathrm{NaCl}$, and no strain had the tolerance of $20 \%(\mathrm{w} / \mathrm{v}) \mathrm{NaCl}$, indicating that the salt tolerance of the strains was mainly between $5 \%$ and $10 \%$. In the determination of alkali resistance, the alkali resistance was determined to be between $\mathrm{pH} 8$ and $10 . \mathrm{Na}_{2} \mathrm{CO}_{3}$ and $\mathrm{NaHCO}_{3}$ were the main soil types in saline-alkali land, and their $\mathrm{pH}$ values were roughly between 8 and 10 .

\section{CONCLUSION}

Experiments were carried out from the separation of salt-tolerant and halophilic bacteria, salttolerant S-G culture medium was used to provide salttolerant environment, and single colony was selected to conduct aseptic isolation of single bacteria. By using the database to carry out the bacterial gene comparison, the halophilic microorganisms in saline soil were isolated and recultured, and the single colony of bacteria was obtained. After PCR amplification technology, through a database of $16 \mathrm{~S}$ rDNA gene sequence similarity comparison and phylogenetic analysis of (heavy) salt resistant bacteria for genotype analysis, to determine whether its for strain has been found, according to the experimental results, the following conclusion: the experiment with directional enrichment method and liquid dilution coated tablet method for screening and identification of salt-tolerant bacteria found in soil bacteria. They found that the genotypes of two samples of the bacteria were significantly different from those of the known bacteria in the gene pool. For the proposed discovery of new strains, among the four submitted strains, the genotypes of the two strains and the 16S rDNA gene sequences of the known strains in the NCBI database were found to be between $97.0 \%-99.2 \%$. Both strains were subspecies of the genus bacillus, which may be newly discovered strains. The results of salt-alkali tolerance test showed that the salt-tolerant strains were all $\mathrm{pH} \mathrm{7-10.} \mathrm{It} \mathrm{is}$ similar to the soil environment in which it grows.

\section{ACKNOWLEDGEMENTS}

This work was supported by Innovation and Entrepreneurship Program for College Students in Heilongjiang Province (201910223085) and 
Heilongjiang Natural Science Foundation (LH2019C050).

\section{REFERENCE}

1. Wu Haiping, Wang Zhenhui, Yang lifu. Analysis on the directional enrichment and diversity of halophilic bacteria in the sedimentary soil of the salt lake of dachan, xinjiang [J]. Bulletin of microbiology, 2010, 37(7): 956-961.

2. Zhao Baishuo, Yang Lifu, Song Lei. Application of moderate halophilic bacteria in biotechnology [J]. Bulletin of microbiology, 2007;34(2):359-362.

3. Margesin R, Schinner F. Potential of halotolerant and halophilic microorganisms for biotechnology [J]. Extremophiles, 2001;5(2):73-83.
4. Ventosa A, Nieto J, Oren A. Biology of moderately halophilic aerobic bacteria [J]. Microbiology and Molecular Biology Reviews, 1998;62(2):504-544.

5. Shen Ping. Microbiology [M]. Beijing: higher education press, 2000.

6. Ren Bacon, Zhou Peijin. Advances in the study of moderate halophiles $[\mathrm{J}]$. Acta microbiologica sinica, 2003;43(3): 427-431.

7. Meng Fanxu. Isolation, identification and application of microorganisms in high-salt environment in the treatment of saline wastewater [D]. Doctoral dissertation, zhejiang university, 2009. 